Нина Говедар, мастер

Филолошки факултет

ngovedar@gmail.com

\title{
ИРОНИЈСКИ ПОСТУПЦИ У ДЈЕЛУ ПЕТРА КОЧИЋА
}

У овом раду циљ нам је да скренемо пажњу на различите иронијске поступке које Петар Кочић користи у својим дјелима. На који начин фреквенција ових поступака кореспондира са тематиком и жанровском припадношћу одређених дјела, те који су то ликови чију карактеризацију Кочић заснива на иронијским премисама. Такође нас занима диференцијација између хуморног, иронијског и сатиричног и њихова функционална примјена у дјелима Петра Кочића.

Кључне ријечи: иронијско, хуморно, сатирично, карактеризација ликова, језик, филозофија.

Рамишљајући о дјелу Петра Кочића, које је, иако обимом невелико, у нашој књижевности и култури оставило изузетно значајан траг, намеће нам се неизбјежно питање: није ли о Кочићу до сада већ све речено? Ипак, прелиставајући доступну литературу и покушавајући да проблематизујемо оне елементе његовог стварања који нас као читаоца интимно узбуђују, дошли смо до закључка да неким Кочићевим поступцима истраживачи готово да се и нису бавили, осим на неком нивоу површног маркирања истих и смјештања у круг стилистичких поступака које је у својим дјелима користио. Из тог разлога нама се 
посебно занимљивом учинила заправо стара реторичка фигура, која у Кочићевим дјелима има врло занимљиву стилску и функционалну карактеристику, те стога свакако заслужује да буде проблематизована.

$* * *$

Имајући на уму то да је иронија као реторичка фигура добро позната и широко коришћена још у старом вијеку, на самом почетку морамо скренути пажњу на то колико, заправо, различитих интерпретација овог појма можемо пронаћи у литератури и колико се оне разликују како у дијахронијском, тако и у синхронијском пресјеку. У Никомаховој етииц Аристотел иронију дефинише као недостатак или умањивање у односу на праву мјеру коју представља искреност или истинољубивост, док је у Рейорици спомиње у вези са смијешним, којим под одређеним околностима треба разбијати озбиљност противника у спору (Стојановић 2003: 16-17). Ипак, захваљујући Платону и његовим списима, иронија ће увијек бити везана првенствено за Сократа и означена као суштински метод његове мајеутике: „Зато он у својим разговорима снагом неумољиве логике разара она мнења која у почетку налази код сабеседника; у том владању дијалектиком се и крије она чувена Сократова иронија“ (Узелац 2003: 69).

Класични реторичари иронију означавају као подсмјешљив начин говора којим се изражава и даје на знање супротно од оног што се мисли, куди се похвалом и слично (Стојановић 2003: 20). О томе колико је иронија културолошки значајна говори нам и списак имена филозофа који су се овом појавом бавили. На првом је мјесту свакако Хегел, који се у својој Истиорији филозофије дубоко посветио Сократу, па према томе и његовом основном методу, односно, управо оном према коме га препознајемо. Како наводи Стојановић (2003: 33), за Хегела је Сократова иронија „манир конверзације, друштвена 
веселост - а нипошто активна свест о ништавности свега“ и манир општег порицања. Са његовим ставом се, рецимо, није слагао Кјеркегор, који је негирао Сократово коришћење ироније као апстраховања конкретних појава, већ је, напротив, тврдио како је Сократ користио управо конкретну предметност како би саговорнику разјаснио и приближио нешто апстрактно. Његово виђење ироније као реторичке фигуре везало се за одређену дозу оймено$c \bar{u} u$ коју је говорник који користи иронијски метод посједовао у говору и процесу мишљења, што свакако можемо посматрати у некој врсти контраста у односу на раније споменуту Хегелову синтагму gрушйвене веселосиии коју иронија за њега представља - „Хегел дакле у Сократовој иронији не види чисту негативност, док Кјеркегор види управо то." (Стојановић 2003: 35)

Питање ироније ипак до данас није заокружено и без обзира на то колико се о њој говорило и колико су више или мање сличних дефиниција дали и реторичари, и филозофи, па и теоретичари књижевности, њена многообухватност још никако није прецизно и систематично изложена. Јавља се у вези са тим питањем још неколико проблема који онемогућавају прецизно дефинисање саме ироније и њене функције у говору/тексту. Наиме, Стојановић (2003: 24) истиче како иронију можемо у књижевном тексту посматрати и као троп и као фигуру, слично односу који у овом контексту постоји код метафоре и алегорије, тј. у случају када је једна ријеч замијењена другом, са ироничним значењем, онда је у питању троп, а када се иронија протеже кроз читав исказ, реченицу или дио текста, онда је у питању фигура. Са друге стране, увијек актуелно је питање дистинкције између хумора, ироније и сарказма, односно дефинисања једног појма на основу другог, како би се што јасније истакли разликовни елементи, што је врло честа пракса. У Рјечнику книжевних иермина (Поповић 2007) налазимо сљедеће дефиниције: 
„ХУМОР - сагледавање света на смешан начин. [...] Управо ће из енглеског језика појам хумор, у модерном значењу 'способности уочавања и приказивања смешне стране ствари' (У. Еко), продрети у све остале европске језике. [...] Теоретичари немачког роматизма сматрали су да је потребно разграничити хумор од других видова комичног, као што су иронија, духовитост, виц, гротеска, пародија, досетка или сатира. [...] За Шопенхауера, хумор је сасвим особена, 'чак узвишеном слична врста смешног', која се не употребљава 'као назив за сваку шалу и лакрдију', такође, овај филозоф прави разлику између ироније и хумора: иронија је објективна, уперена на другог и представља шалу скривену иза озбиљности, док је хумор субјективан, постоји само за наше сопствено ја и представља озбиљност која се крије иза шале; отуда је хумор 'двоструки контрапункт ироније.“" (272-274)

„ИРОНИЈА - стилска фигура значења којом се, најчешће помоћу хумора, исказује супротан садржај од непосредно изреченог. Сам назив вероватно потиче из античке комедије у којој се понекад појављивало лице Еирон, оличење лицемера који глуми глупака и увек изговара реченице сасвим супротног значења од намераваног. Иронију, дакле, одређују два суштинска елемента - негација и хумор.“ (299-300)

„САРКАЗАМ - у реторици врста заједљиве, пакосне шале, подругљиве и горке ироније; сарказам је немилосрдна поруга и злонамеран прекор уз обавезан подсмех, неретко заснован на парадоксу, тј. на нескладу између дословног значења речи и контекста који прати њихово изрицање. Заједно с иронијом, сарказам се заснива на негативном етосу смеха и прожет је жељом да се противник порази и понизи.“ (649) 
Када је у питању дјело Петра Кочића нас занима на трагу којег од наведених филозофских праваца се налази његово схватање и употреба ироније, ${ }^{1}$ те на који начин је могуће поставити паралелу разликовности између ироније и сарказма у Кочићевим текстовима. Такође, у фокусу интересовања налазе се и поједини ликови, чија је једна од најупечатљивијих карактеристика управо коришћење иронијских исказа. С тим у вези, у наставку ћемо издвојити неколико примјера из Кочићевих текстова на којима можемо показати сву специфичност Кочићеве ироније, те је смјестити у одговарајући филозофски и реторички концепт.

Радован Вучковић пише како је „Петар Кочић [je] био од оних писаца, попут Крауса, чија су књижевна и политичка делатност обједињене и усмерене према јединственом циљу: борби против бирократске самовоље која уништава духовне вредности народа“ (Вучковић 2009: 19). На првом мјесту, свакако, говоримо о Кочићевој једночинки Јазаваu, üpeg cygoм. Иако у својој суштини сатирични комад који се са много подсмјеха односи према ситуацији у окупираној Босни и њеном сељаку, како бисмо јасно сагледали све нијансе којима Кочић слика стварност око себе, неопходно је да обратимо пажњу и на иронијске поступке које користи у овом дјелу. Како наводи Ненад Новаковић (2010: 75) Давид Штрбац „се труди да се у свакој изговореној ријечи подсмијехне, а посебна нетрпељивост и тешкоћа подношења непријатеља чини га посебно јасним и на језику отровним. [...] Говор му је препун двосмислености и жаока које он увијек

1 Филозофија и књижевност умногоме зависе једна од друге и допуњују се; о њиховом саодносу писао је и Новица Милић у Моgерно схватиане књижевностии (Београд: Завод за уџбенике и наставна средства, 2002). 
окреће против окупаторског режима, судства, владе, поробљивача“. Тако на самом почетку налазимо реченицу „Добар дан, ілавай и, царски господини!“ (Кочић 2012: 89) коју Давид Штрбац изговара ступајући у судницу. С обзиром на то да Давид користи погрешну ријеч, онако „по сељачки“ на први поглед ово је примјер исказа који је подсмјешљив, али не и супротан од онога што Давид мисли, будући да ријеч іллавайи користи умјесто ӣоїлавити и, а по аналогији са: онај који има велику главу је паметан. Међутим, уколико у обзир узмемо и ово претпостављено значење изведено по аналогији, закључујемо како семантички, уколико имамо на уму све оно што Давид (и његови сународници) мисле о окупаторској влади, овоме исказу врло лако можемо приписати и ово потоње, дакле, значење супротно од онога изреченог, чиме се потврђује иронијска вриједност исказа.

Даље, Давид изговара реченицу „Мени је овај славни суд млого добра учинио. Од млоге ме је биједе и невоље ослободио...“ (Кочић 2012: 97) алудирајући на то што му је та иста власт „наопаког и злочестог“ сина послала у војску у Грац, гдје је и страдао, за шта му је царство послало три форинте као наіраgy. „'О, добре царевине, крст јој љубим!', лијепо је јаукнуо оg раgосиич..." (Кочић 2012: 97). У овом контексту свакако се ишчитава иронија какву најчешће подразумијевамо, а која представља, дакле, потпуну супротност изреченог у односу на оно што се мисли. Сличним поступком се Давид Штрбац користи и када изражава народно незадовољство владавином аустроугарске царевине у Босни: „О, ми смо задовољни! Притиснуло нас добро са свију страна; og некакве силне смо се милине умритвили йа јеgва gишемо..." (Кочић 2012: 105). Давид Штрбац свакако је један од најупечатљивијих ликова наше књижевности, који свој бунт потлаченог сељака у окупираној земљи исказује кроз константан баланс између лажног додворавања властима 
и прикривене, иронијски исказане, критике администрацији, управи и самом царству, што Јован Дучић биљежи овако: „Ничег у нас није било написано ни духовитије ни трагичније него тај Штрпчев хумор, његова привидна наивност, беспомоћни протест човека кога бичују по очима и по устима, а који нема довољно руку да подави и покоље сав тај олош, који се по Босни нагурао под изговором да ту земљу просвети и уљуди“ (Дучић 2001: 184).

Ипак, није Штрбац једини од Кочићевих јунака чија је иронија вриједна наше пажње. У приповијеци Ракијо, мајко Шошљага изговара здравицу која је сва састављна од готово парадоксалних, иронијски интонираних поређења:

„Силни, ћесерокраљски геренале и војводо! (То сам му ја пришапно.) Вала $\bar{u} и$ og неба gо ирне земъе на твоме дочеку и чествовању! Дабогда се ти, добри чојече и медено љето моје, дичио и поносио својом силом и моћи ко Локвари крађом, Дујаковии свађом, ко Павићи весетарима, а Тайићи кайарима; ко Гомјеница gелијама и калуђерима, а Лусићи ӣойовима; ко Сйричићи йиром, а Добрна ирровом; ко Перван уяовицама, а Мелина иурама; ко Кочића Главица висином, а Тимар низином; ко Кола йлоскама, а Шљивно ильивама; ко Рекавице касайлуком, а Баға Лука іаздинским лойовлуком и невјерлуком! Живио! И наздравље!“ (Кочић 1965: 85)

Сличним поступком у истој приповијеци служи се и Симеун, који изговара похвалу иронизовану до те мјере, да остали сељаци не разумијевају његов прави наум. ${ }^{3}$

2 Подвлачење наше.

3 „Ћесерокраљска гереналино и свијетла јуначка, војинствена главешино! Дична је ово и благословљена земља ко ниједна земља под небесним сводом. Свима се њезиним другама са истока сунце рађа, а ево њој се оће са запада да роди и да је 
Оваквим примјерима обилује готово цјелокупно Кочићево књижевно, и не само књижевно, дјело. Понекад је та иронија оштра и горка, и у пуном смислу онаква каквом ју је Кјеркегор дефинисао - као „свеобухватно начело негације, које не погађа само нешто појединачно у свету него његову целину, и то у одређеном повесном тренутку“ (Стојановић 2003: 34). Са друге стране, ипак, јавља се неријетко и она Хегеловска друшишвена веселости која заправо представља исказ духовитости и виспрености мисли босанског, крајишког сељака, и осим што критикује све оно што стоји у вези са аустроугарском окупацијом и новим временима, ипак, осликава и менталитет змијањског човјека, који се ни у таквим, тешким условима не одриче своје слободе говора, макар он морао бити замаскиран, изврнут или изокренут у иронијски исказ, саговорнику проходан само на површном, односно комуникативном нивоу. Уопште йосииојаґе дубљих или двоструких значењских слојева њему остаје непознаница, тако да се истинитост исказа уопште не доводи у питање. Тиме, заправо овакви иронијски поступци одударају од Сократовог метода, јер док у његовој мајеутици свака употреба ироније нужно води ка сазнању, овдје је иронија

топло и шчедро огрије, јер је она одувијек, од искони, била у милости код господа бога и код божји, свети угодника, а и богоносни отаца. Ћесерокраљска гереналино и свијетла, јуначка, војинствена главешино, и браћо моја рођена, чудесна је то судбина и удес нашег премилог отечества које већ пет стотина година цвили под тешким наџаком агарјанске, паклене силе и зулума! Чудесна је то судбина, велим, али бог премилостиви и све седам царевина тако су шћели, па је, ево, тако и било. Викните сви: Вала им на њиовом премилостивом дару!

- Вала им на њиовом премилостивом дару! - викнуше сви осим покојног Партеније, кога стоструке сузе облише јер је он јеgини разумео и у ілави својој расирресо моју неразумљиву бешјеgу." (Кочић 1965: 86), подвлачење наше. 
разумљива само оној страни која је употребљава и стога саговорнику потпуно непроходна. Кочићева употреба иронијских поступака најприје се може поистовјетити са Хегеловим схватањем ироније, која не садржи ону озбиљност језичког израза који јој Кјеркегор приписује.

Ипак, зашто тврдимо да су сви наведени поступци код Кочића прије иронија него сарказам? Зато што сарказам поздразумијева „негативни етос смијеха“, жељу за изругивањем и понижавањем саговорника, а Кочићев израз, иако прецизан и оштар у свој љепоти народног језика (о којој су многи у вези са Кочићем говорили $\left.{ }^{4}\right)$ примарно има функцију ослобађања оног ко говори и његовог интелектуалног узвишења, а не унижавања онога коме се говори. О иронији морамо говорити чак и када је у питању дио приповијетке Ракијо, мајко у којој „онај иза каце“ прилично саркастично добацује Симеуну Ђаку:

„- Не шједај, Симеуне, на ту клупу! викну Мићан и подмаче му свој столац да сједне. - Малоприје нам се не'отице просу ком, па је, прошћеш, мокра.

- Није ни он најсувљи, промрмља неко иза каце.

- Шта ви то причате о мени? - учини се Симеун, као да и не чу, што онај у мраку рече.

- Збиља, брез шале, шта ви то причате о мом Симеундашу, о мом старом делији и

4 Види нпр.: Андрић, Иво. „Земља, људи и језик Петра Кочића“ у Уметиник и юеїово gело: Есеји II. Сабрана дјела Иве Андрића, књ. 13. (Београд: Просвета, 1978), стр. 157-180; Скерлић, Јован. „Петар Кочић“ у Кюижевне критиике. (Београд: Рад, 1986), стр. 173-184; Секулић, Исидора. „Петар Кочић [дело]“ у Јауци са 3мијаюа. Библиотека Српска књижевност у сто књига, књ. 46. (Нови Сад: Матица српска, 1972), стр. 37-55. 
бранитељу ове обитељи и ове наше свете ћабе? - рече врло меко, готово побожно, отац Сопронија и сједе на праг од подрума. - Ја најволим на прагу...

- Og йоgрума! $!^{5}$ - додаде неко из мрака.“ (Кочић 1965: 52)

Наиме, иако оба подвучена исказа заправо представљају сарказам, битно је обратити пажњу на контекст у којем се јављају. Раније смо навели како је за сарказам специфична заједљивост, односно злонамјеран прекор упућен саговорнику, а овдје, ипак, то није случај. Наиме, тек неколико редова изнад, „онај иза каце“ брани Симеуна пред осталима окупљеним око котла: „Не гуди ни ти, Глишо, баш тако дебело! - чу се онај иза каце и опет зијевну. - Пију, а пили су, драгости моја, и други.“ (Кочић 1965: 51), што нам јасно указује на то да у његовим изјавама има одређене дозе пријекора, али не и злобе или жеље да се саговорник понизи и порази. Имајући то на уму, дакле, закључујемо како је овај исказ много ближи иронији, у оном смислу негирања реалности, односно извртања исте. То најбоље можемо показати тиме што би смисао исказаног остао исти и да је исказ „Није ни он најсувљи.“ замијењен чистом ироничном реченицом попут: „А он (Симеун) је, срећом, сув“.

Треба, такође, истаћи да је и у дјелу Петра Кочића врло очигледна дистинкција између ироније као намјерног и хумора као спонтаног поступка. О разликовности између промишљености иронијског поступка и непосредности смијеха и хумора Богдановић (2005: 23) пише: „Смех, осмех и подсмех су физичке реалности, психолошки индуковане промене на равни бића. Иронија, сатира и сарказам су интелектуалне активности засно-

5 Подвлачење наше. 
ване на неслагању високог степена. Оне су оријентисани смех који прати говорни израз (сентименти као организацију осећања)“. Иронија је за Кочићевог јунака легитиман начин борбе не само против туробности живота на крајишкој планини, већ и против оних који су у ту исту Крајину дошли са идејом да тај начин живота мијењају.

\section{Литература}

I

Кочић 1965. Кочић, Петар. Изабране ӣрийоветике и Јазаваи, uрpeg суgом. Београд: Народна књига, 1965.

Кочић 2012. Кочић, Петар. Јазаваи, иреg суgом. Београд: JPJ, 2012.

\section{II}

Андрић, Иво. „Земља, људи и језик Петра Кочића“ у Умештник u юеі̄ово gело: Есеји II. Сабрана дјела Иве Андрића, књ. 13. Београд: Просвета, 1978.

Богдановић, Недељко. „Комика између осмеха и подсмеха“ у Комично у кулитури Срба и Буіара/Комичнотио в кул-

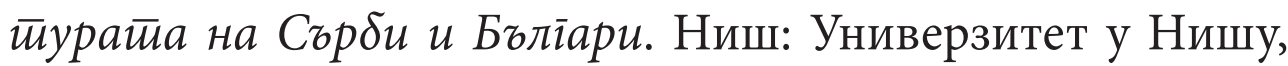
Филозофски факултет, 2005. 19-26.

Вучковић, Радован. „Приповедач Петар Кочић у свом и нашем времену“ у Пейар Кочић gанас, зборник радова (Научни скуп Петар Кочић данас, Бања Лука, 10. и 11. новембра 2007., приредио Станиша Тутњевић). Бања Лука: Академија наука и умјетности Републике Српске, 2009.

Дучић, Јован. „Петар Кочић“ у Моји сайуйници. Београд: Рад, Подгорица: Октоих, Требиње: Дучићеве вечери поезије, 2001.

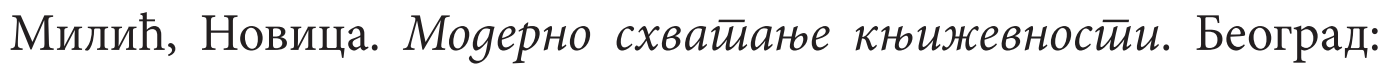
Завод за уџбенике и наставна средства, 2002.

Новаковић, Ненад. Поеитика и језик у gјелу Петира Кочића. Бања Лука: Бесједа, Арс Либри, 2010. 
Popović, Tanja. Rečnik književnih termina. Beograd: Logos art, 2007.

Секулић, Исидора. „Петар Кочић [дело]“ у Јауци са Змијања. Библиотека Српска књижевност у сто књига, књ. 46. Нови Сад: Матица српска, 1972.

Скерлић, Јован. „Петар Кочић“ у Кюижевне критиике. Београд: Рад, 1986.

Стојановић, Драган. Иронија и значене. Друго, допуњено издање. Београд: Завод за уџбенике и наставна средства, 2003.

Uzelac, Milan. Istorija filozofije I: (istorija filozofije do Dekarta). Drugo, izmenjeno izdanje. Vršac: Viša škola za obrazovanje vaspitača, 2003.

Nina Govedar

\section{IRONIC PROCEDURES IN THE WORK OF PETAR KOČIĆ}

\section{Summary}

In this paper our aim was to draw attention to various ironic procedures Petar Kočić used in his work. How the frequency of these procedures does correspond to the theme and genre affiliation to certain works, and what are the characters whose characterization Kočić based on ironic premises. Also we were interested in differentiation between the humorous, ironic and satirical and their functional application in the works of Petar Kočić.

Key words: ironic, humorous, satirical, characterization of characters, language, philosophy. 